\section{Evaluation of different instrumentation systems for apical extrusion of debris}

\section{Farklı enstrümentasyon sistemleri kullanılarak yapılan kök kanal preparasyonu sırasında apikalden taşan debris miktarının değerlendirilmesi}

\author{
Assist. Prof. Recai Zan \\ Cumhuriyet University, Faculty of Dentistry, \\ Department of Endodontics, Sivas \\ Assoc. Prof. Hüseyin Sinan Topçuoğlu \\ Erciyes University, Faculty of Dentistry, \\ Department of Endodontics, Kayseri \\ Prof. İhsan Hubbezoğlu \\ Cumhuriyet University, Faculty of Dentistry, \\ Department of Restorative Dentistry, Sivas \\ Prof. Jale Tanalp \\ Yeditepe University, Faculty of Dentistry, \\ Department of Endodontics, Istanbul
}

Assoc. Prof. Meric Karapınar Kazandağ Yeditepe University, Faculty of Dentistry, Department of Endodontics, Istanbul

Received: 2 November 2016

Accepted: 21 January 2017

DOI: 10.5505/yeditepe.2017.21931

\author{
Corresponding author: \\ Assist. Prof. Recai Zan \\ Department of Endodontics \\ Faculty of Dentistry, Cumhuriyet University, \\ 58140 Sivas, Turkey \\ Tel: +90 3462191010 / 2764 \\ E-mail: drrecaizan@hotmail.com
}

\section{SUMMARY}

Aim: The aim of present study was to investigate the amount of debris extruded apically during preparation with ProTaper Gold (PTG; Dentsply Maillefer, Ballaigues, Switzerland), WaveOne Gold (WOG; Dentsply Maillefer), One Shape New Generation (OSNG; MicroMega, Besancon, France), Twisted File Adaptive (TFA; SybronEndo, Orange, CA, USA), and K3XF (SybronEndo) nickel-titanium instrumentation systems.

Materials and Method: Seventy-five extracted human single-rooted mandibular premolar teeth were randomly assigned to 5 groups $(n=15)$. The root canals were prepared according to the manufacturers' instructions using the PTG, WOG, OSNG, TFA, and K3XF instruments. Debris apically extruded during instrumentation was collected in pre-weighed eppendorf tubes. The eppendorf tubes were then stored in an incubator at $70^{\circ} \mathrm{C}$ for 5 days. The tubes were weighed again, and the difference between the initial and final weights was calculated. The data were statistically analyzed using oneway ANOVA and Tukey's post-hoc tests.

Results: The TFA group extruded significantly more debris compared with all other groups $(P<0.05)$. Statistically, K3XF and OSNG groups were associated with more debris extrusion compared with the WOG and PTG groups $(P<0.05)$. There was no statistically significant difference between the K3XF and OSNG groups $(P>0.05)$. Additionally, there was no statistical difference between the WOG and PTG groups in the amount of extruded debris $(P>0.05)$.

Conclusions: Under the conditions of this study, all instrumentation systems resulted in apical extrusion of debris. The WOG and PTG instrumentation systems caused the least amount of extruded debris compared with the other groups. The amount of apically extruded debris may vary according to metallurgy, kinematics and design of the instrument used. Key Words: Apical extrusion, rotary files, gold-file systems

\section{ÖZET}

Amaç: Bu çalışmanın amacı, Protaper Gold (PTG; Dentsply Maillefer, Ballaigues, Switzerland), WaveOne Gold (WOG; Dentsply Maillefer), One Shape New Generation (OSNG; MicroMega, Besancon, France), Twisted File Adaptive (TFA SybronEndo, Orange, CA, USA), and K3XF (SybronEndo) nikel-titanyum enstrümantasyon sistemleri ile preparasyon boyunca apikalden taşan debris miktarını araştırmaktır.

Gereç ve Yöntem: Yetmiş beş insan tek köklü mandibular premolar diş rastgele olarak 5 gruba ayrılmıştır $(n=15)$. Kök kanalları PTG, WOG, OSNG, TFA, ve K3XF eğeleri kullanılarak üreticinin talimatlarına göre prepare edilmiştir. Enstrümantasyon boyunca apikalden taşan debris önceden tartılmış ependorf tüplerin içinde toplanmıștır. Ependorf tüpler daha sonra 5 gün boyunca $70^{\circ} \mathrm{C}^{\prime}$ de bir inkübatör içerisinde muhafaza edilmiștir. Tüpler yeniden tartıldı ve ilk ve son ağırlıkları arasındaki fark hesaplanmıștır. Veriler istatistiksel olarak tek yönlü ANOVA ve Tukey post-hoc testleri kullanılarak analiz 
edilmiştir.

Bulgular:TFAgrubu diğer tüm gruplarilekarşılaştıııldığında önemli ölçüde daha fazla debris taşırmıştır $(P<0,05)$. Istatistiksel olarak, K3XF ve OSNG grupları, WOG ve FTG gruplar ile karşılaştırıldığında daha fazla debris taşması ile ilişkili bulunmuştur $(P<0,05)$. K3XF ve OSNG gruplar arasında istatistiksel olarak anlamlı bir fark saptanmamıştır $(P>0,05)$. Buna ek olarak, WOG ve FTG grupları arasında apikalden taşan debris miktarında istatistiksel olarak anlamlı bir farklıık bulunmamıştır $(P>0,05)$.

Sonuç: Bu çalışmanın koşulları altında, tüm enstrümantasyon sistemleri debrisin apikal ekstrüzyonu ile sonuçlandı. WOG ve PTG enstrümantasyon sistemleri diğer gruplar ile karşılaştıııldığında en az miktarda debris ekstrüzyonuna neden olmuştur. Apikalden taşan debris miktarı, kullanılan enstrümanın metalürjisine, kinematiğine ve tasarımına göre değişebilir.

Anahtar Kelimeler: Apikal ekstrüzyon, rotary eğeler, gold-file sistemler

\section{INTRODUCTION}

The extrusion of necrotic pulp, bacteria, and irrigants may be occured during root canal instrumentation into the periradicular tissues. Apically extruded materials have clinically been shown to cause discomfort, postoperative inflammation and flare-up, and apical healing failure. ${ }^{1,2}$ It is generally accepted that all preparation techniques and instruments have a potential in terms of debris extrusion. ${ }^{3,4}$ The extruded debris may vary with the instrumentation technique used and the design of the root canal instruments. ${ }^{5,6}$ Rotary nickel-titanium (Ni-Ti) instruments provided less extruded debris than hand files. ${ }^{7,8}$

The ProTaper Gold (PTG; Dentsply Maillefer, Ballaigues, Switzerland) system is a new system that shares an identical instrument design with a triangular cross section and a variable progressive taper. PTG is manufactured using advanced proprietary metallurgy that reportedly increases its flexibility and resistance to cyclic fatigue. ${ }^{9}$ Another recently introduced system is WaveOne Gold (WOG; Dentsply Maillefer), a new generation of reciprocating files. The manufacturers of WOG claim that WOG technology boosts cyclical fatigue resistance and reduces the screwing effect. WOG design has also been optimized to increase cutting efficiency.

The new Twisted File Adaptive system (TFA; SybronEndo, Orange, CA, USA) uses a combination of continuous rotation and reciprocating motions. ${ }^{10}$ The manufacturer claims that the adaptive technology and the twisted file design that incorporates R-phase technology increases debris removal and flexibility.

The K3XF (SybronEndo) is the next generation of the K3 (SybronEndo) instrument system. K3XF provides clinicians an improved level of flexibility and resistance to cy- clic fatigue with the proprietary R phase technology. One Shape New Generation (OSNG; MicroMega, Besancon, France) is another new file system that uses a traditional, continuous, rotational motion. The OSNG file has an asymmetric cross-sectional geometry and longer pitch. ${ }^{11}$ The manufacturer claims that the design of the OSNG file increases the available volume for upward debris elimination.

There is no research yet on the apically debris extrusion following the root canal treatment using PTG, WOG, and OSNG instruments. Therefore, the evaluation of debris extrusion was intended during root canal preparation using WOG, PTG, OSNG, TFA, and K3XF rotary Ni-Ti instruments.

\section{MATERIALS AND METHODS}

Freshly extracted human mandibular incisor teeth with a single root and canal and a curvature $<5^{\circ}$, in accordance with Schneider's criteria ${ }^{12}$ were used for this study. The diamond burs (Diatech, Coltene Whaledent, Altststten, Switzerland) were used to prepared endodontic access cavities under water-cooling. Following the access cavity preparation, canals that exceeded the International Standards Organization (ISO) size 15 were discarded, ${ }^{13}$ and seventy five teeth were included. The cusp edge of each tooth was flattened to standardize the lengths of samples to $19 \mathrm{~mm}$. The working length (WL) was determined by subtracting $1 \mathrm{~mm}$ from this measurement.

\section{Debris Collection}

Debris collection was done according to Myers and Montgomery' protocol. ${ }^{14}$ The equalization of air pressure was provided with $25-\mathrm{G}$ needle that placed into the stopper. Then, each stopper with the tooth and the needle was attached to its eppendorf tube and the tubes were fitted into vials. The prepared eppendorf tubes were weighed using a microbalance (Sartorius AG, Göttingen, Germany) before root canal preparation. For each tube, consecutive measurements were repeated 3 times and the mean value was recorded. All teeth were coded and then randomly allocated into 5 groups of 15 specimens each.

\section{Experimental Groups and Instrumentation Proce- dures \\ PTG Group}

PTG instruments were used to prepare the root canals. The following sequence was used: SX file to $1 / 2$ of the WL, S1 and S2 files to 2/3 of the WL, and F1 files (size 20, 0.07 taper) and F2 files (size 25, 0.08 taper) to the full WL. For SX and S1, instruments were used at $300 \mathrm{rpm}$ with a torque of $3 \mathrm{Ncm}, 1.5 \mathrm{Ncm}$ for $\mathrm{F} 1$ instruments, and $2 \mathrm{Ncm}$ for F2 instruments. 


\section{WOG Group}

The root canals were instrumented using a WOG Primary file (size $25,0.08$ taper) in a reciprocating working motion at $300 \mathrm{rpm}$.

\section{TFA Group}

TFA (SybronEndo) instruments were used and set to the TFA program of their motor, which allows for torque control and stability, in a sequence of ML1 (size 25, 0.08 taper). ML1 instruments were carefully placed into the canal until the WL was achieved using a Sybron Elements motor (Sybron Endo) set at the adaptive motion. Each instrument was moved in the apical direction using an inand-out motion within a span of about $3 \mathrm{~mm}$.

\section{OSNG Group}

The root canals were prepared with OSNG (Micro-Mega) instruments (size 25, 0.06 taper). In-and-out movements were made with minimal pressure at a rotational speed of $400 \mathrm{rpm}$ and $2 \mathrm{Ncm}$ torque at the WL. A torque-controlled electric motor (VDW Silver; VDW) was used.

\section{K3TMXF Group}

K3XF instruments (Sybron Endo) were used with a gentle in-and-out motion at a rotational speed of $400 \mathrm{rpm}$. K3XF files (size 25, 0.04 taper and size 25, 0.06 taper) were used at the WL. All systems were used in the file sequence recommended by the respective manufacturer. Canal patency was checked using a size $10 \mathrm{~K}$-file. A total of $10 \mathrm{ml}$ distilled water was used in each canal for irrigation. A single operator prepared the all root canals.

\section{Evaluation of Apically Extruded Material}

On completion of the instrumentation procedure, the root was washed with $1 \mathrm{ml}$ distilled water in the tube to collect the debris adherent to external surface of the apex. The evaporation of irrigants used during instrumentation before weighing the dry debris was provided with storage of tubes in an incubator at $70^{\circ} \mathrm{C}$ for 5 days. ${ }^{6}$ By subtracting the original weight of the empty eppendorf tube from the gross weight, the net weight of the dry debris was determined.

\section{Statistical Analysis}

The statistically analysis was performed with a one-way analysis of variance (ANOVA). For multiple comparisons, Tukey's post hoc test was used. The level of significance was set at $\mathrm{P}<0.05$. All statistical analyses were done with SPSS version 20.0.

\section{RESULTS}

The mean, minimum, and maximum extrusion values (g) for each group were shown in Table 1. TFA group showed statistically greater amount of debris than other groups $(P<0.05)$. Although OSNG and K3XF groups indicated no significant difference $(P>0.05)$, both groups resulted in more debris extrusion than the WOG and PTG groups $(P<0.05)$. No significant difference was observed between the PTG and WOG groups ( $P>0.05)$.

Table 1: Mean, minimum and maximum values (g) according to groups were shown in the table.

\begin{tabular}{|c|c|c|c|}
\hline Groups & Mean (SD) & Minimum & Maximum \\
\hline $\begin{array}{c}\text { Group 1 } \\
\text { ProTaper Gold }\end{array}$ & $\begin{array}{c}0.0006 \\
(0.00038) \mathrm{a}\end{array}$ & 0.00011 & 0.00119 \\
\hline $\begin{array}{c}\text { Group 2 } \\
\text { WaveOne Gold } \\
(0.00027) \mathrm{a}\end{array}$ & 0.00023 & 0.00110 \\
\hline $\begin{array}{c}\text { Group 3 } \\
\text { Twisted File }\end{array}$ & $\begin{array}{c}0.0023 \\
(0.00040) \mathrm{b}\end{array}$ & 0.00189 & 0.00302 \\
\hline $\begin{array}{c}\text { Group 4 } \\
\text { OneShape New } \\
\text { Generation }\end{array}$ & $\begin{array}{c}0.0012 \\
(0.00038) \mathrm{C}\end{array}$ & 0.00078 & 0.00180 \\
\hline $\begin{array}{c}\text { Group 5 } \\
\text { K3xf }\end{array}$ & $\begin{array}{c}0.0013 \\
(0.00032) \mathrm{C}\end{array}$ & 0.00089 & 0.00188 \\
\hline
\end{tabular}

By the One way ANOVA, $F=55.183, P=0.000(P<0.05)$

Values $(\mathrm{g})$ with same superscript letter show no statistically different at $\mathrm{P}<0.05$ by Tukey's post-hoc Test.

\section{DISCUSSION}

In the present study, to prevent WL loss or non-standardized preparation, straight single-rooted mandibular premolar teeth were included. An evaluation of the efficacy of apical constriction damage on extruded debris determined that an increase in the diameter of the apical patency may increase the extrusion of debris. ${ }^{15}$ In the present study, a size $15 \mathrm{~K}$-file was advanced to the $\mathrm{WL}$ to control the size of the minor foramen. Some investigators suggest the use of a barrier material to simulate apical resistance. ${ }^{5,16}$ However, barrier materials, such as agar or foam may absorb irrigation solution and debris. Therefore, periodontal tissue was not imitated with any material. An in vivo treatment may indicate various results because the periapical tissues, which serve as a natural barrier, may inhibit apical extrusion of debris. ${ }^{17}$ Therefore, the results of the present study should not be directly extrapolated to the clinical environment.

Sodium hypochlorite is commonly used as an irrigation solution in root canal preparation. In present study, distilled water was preferred as an irrigation solution to prevent sodium hypochlorite crystallization. ${ }^{13}$ Side-vented needles extrude less irrigant compared with regular needles. ${ }^{5}$ Therefore, side-vented needles were used to minimize irrigation extrusion in all groups.

The amount of apically extruded debris from new instrument systems was evaluated in the present study. Each 
instrument system tested had a different design, recommended number of files, and kinematics. Continuous rotation movement may improve coronal transportation of dentin chips and debris by acting like a screw conveyor, but reciprocal motion may enhance debris transportation toward the apex. 3 PTG, OSNG, and K3XF are designed to work with continuous rotational movement. TFA is designed to use motion similar to continuous rotation, but when load is applied, the system converts to a reciprocal motion, which could reduce cyclic fatigue of the file. ${ }^{18}$

The TFA instrument extruded the greatest amount of debris. Instrumentation using K3XF and OSNG files resulted in less debris extrusion compared with TFA. Although there was an insignificant difference between K3XF and OSNG, K3XF files extruded slightly more debris. A possible explanation for this is that the K3XF opener file removes more dentin in the coronal section than OSNG. Thus, the greater coronal width may facilitate the K3XF transport of debris toward the coronal area, thereby decreasing apically extruded debris. Another possibility is that the variable pitch of K3XF increases the transport of debris to the coronal section. The longer pitch design of the OSNG file may increase the volume of upward debris elimination. The amount of apical debris extrusion can be related to root canal anatomy and/or the instrumentation technique. ${ }^{19-22}$ Currently, no method completely avoids debris extrusion. A greater amount of debris extrusion was detected in the TFA group compared with the OSNG and K3XF groups. This may be due to the reciprocal motion of TFA when it is subjected to pressure and resistance. Reciprocation movement increases debris extrusion compared with continuous rotation movement. ${ }^{3}$ The least amount of extruded debris was observed in the WOG and PTG groups. These results might be explained by differences in the metallurgy and design of the instruments. WOG instruments are manufactured using a new proprietary thermal process in which the ground $\mathrm{Ni}-\mathrm{Ti}$ files are heat-treated and slowly cooled, producing a super-elastic Ni-Ti file. This elasticity may cause less debris extrusion compared with the other groups. Furthermore, the ogival, roundly tapered, and semi-active features of WOG reduce the mass at the center of the tip and improve its penetration into any canal with a confirmed, smooth, and reproducible glide path. These features may explain the minimal amount of debris extrusion caused by WOG. PTG are manufactured from different alloys achieved through an enhanced proprietary heat treatment technology. This provides the instruments with greater flexibility and a reduced restoring force..$^{23-25}$ These features may play a crucial role in extruding less debris. PTG also has a different geometry: smaller dimensions, off-centered mass, and a regressive taper. The centering ability of the PTG instruments may maintain greater dentin thickness of the root canal and this may explain why it resulted in less apically extruded debris. ${ }^{25}$ Additionally, the low transportation and canal wall contact values of the WOG and PTG instrumentation systems may show variances. ${ }^{26,27}$ These differences in the WOG and PTG systems may be other significant reasons for less extruded debris than the other systems. WOG and PTG are safe and efficient systems for preparing canals. Sophisticated metallurgy and design of WOG and PTG result in improved flexibility and cyclic fatigue life with less binding and torsional stress on the file during work. Specifically, the WOG single file system reduces preparation time.

\section{CONCLUSIONS}

All instrument systems cause apical debris extrusion in extracted mandibular premolar teeth. OSNG, TFA, and K3XF instruments caused more debris extrusion compared to WOG and PTG instruments. Within the limitations of this study, one can conclude that metallurgy and design of the instrument may affect the amount of apically extruded debris.

\section{REFERENCES}

1. Seltzer S, Naidorf IJ. Flare-ups in endodontics: I. etiological factors. J Endod 1985; 11: 472-478.

2. Nair PN. On the causes of persistent apical periodontitis: a review. Int Endod J 2006; 39: 249-281.

3. Bürklein S, Schäfer E. Apically extruded debris with reciprocating single-file and full-sequence rotary instrumentation systems. J Endod 2012; 38: 850-852.

4. Xavier F, Nevares G, Romeiro MK, Gonçalves K, Gominho $L$, Albuquerque $D$. Apical extrusion of debris from root canals using reciprocating files associated with two irrigation systems. Int Endod J 2015; 48: 661-665.

5. Altundasar E, Nagas E, Uyanik O, Serper A. Debris and irrigant extrusion potential of 2 rotary systems and irrigation needles. Oral Surg Oral Med Oral Pathol Oral Radiol Endod 2011; 112: 31-35.

6. Koçak S, Koçak MM, Sağlam BC, Türker SA, Sağsen B, Er Ö. Apical extrusion of debris using self-adjusting file, reciprocating single-file, and 2 rotary instrumentation systems. J Endod 2013; 39: 1278-1280.

7. Reddy SA, Hicks ML. Apical extrusion of debris using two hand and two rotary instrumentation techniques. $J$ Endod 1998; 24: 180-183.

8. Kuştarci A, Akpinar KE, Er K. Apical extrusion of intracanal debris and irrigant following use of various instrumentation techniques. Oral Surg Oral Med Oral Pathol Oral Radiol Endod 2008; 105: 257-262.

9. Arias A, Singh R, Peters OA. Torque and force induced by ProTaper Universal and ProTaper Next during shaping of large and small root canals in extracted teeth. J Endod 2014; 40: 973-976. 
10. Gergi R, Arbab-Chirani R, Osta N, Naaman A. Micro-computed tomographic evaluation of canal transportation instrumented by different kinematics rotary nickel-titanium instruments. J Endod 2014; 40: 1223-1227.

11. Capar ID, Ertas H, Ok E, Arslan H, Ertas ET. Comparative study of different novel nickel-titanium rotary systems for root canal preparation in severely curved root canals. J Endod 2014; 40: 852-856.

12. Schneider SW. A comparison of canal preparations in straight and curved root canals. Oral Surg Oral Med Oral Pathol Oral Radiol Endod 1971; 32: 271-275.

13. Huang $X$, Ling J, Wei $X$, Gu L. Quantitative evaluation of debris extruded apically by using ProTaper Universal Tulsa rotary system in endodontic retreatment. J Endod 2007; 33: 1102-1105.

14. Myers GL, Montgomery S. A comparison of weights of debris extruded apically by conventional filing and Canal Master techniques. J Endod 1991; 17: 275-279.

15. Tinaz AC, Alacam T, Uzun O, Maden M, Kayaoglu G. The effect of disruption of apical constriction on periapical extrusion. J Endod 2005; 31: 533-535.

16. Hachmeister DR, Schindler WG, Walker WA, Thomas DD. The sealing ability and retention characteristics of mineral trioxide aggregate in a model of apexification. $J$ Endod 2002; 28: 386-390.

17. Yeter KY, Evcil MS, Ayrancı LB, Ersoy I. Weight of apically extruded debris following use of two canal instrumentation techniques and two designs of irrigation needles. Int Endod J 2013; 46: 795-799.

18. Gambarini G, Testarelli L, De Luca M, Milana V, Plotino G, Grande NM, Rubini AG, Al Sudani D, Sannino G. The influence of three different instrumentation techniques on the incidence of postoperative pain after endodontic treatment. Ann Stomatol (Rome) 2013; 4: 152-155.

19. Tanalp J, Kaptan F, Sert S, Kayahan B, Bayirli G. Quantitative evaluation of the amount of apically extruded debris using three different rotary instrumentation systems. Oral Surg Oral Med Oral Pathol Oral Radiol Endod 2006; 101: 250-257.

20. Bidar M, Rastegar AF, Ghaziani $P$, Namazikhah MS. Evaluation of apically extruded debris in conventional and rotary instrumentation techniques. $\mathrm{J}$ Calif Dent Assoc 2004; 32: 665-671.

21. Mangalam S, Rao CV, Lakshminarayanan L. Evaluation of apically extruded debris and irrigant using three instrumentation techniques. Endodontology 2002; 14: 19-23.

22. De-Deus GA, Nogueira Leal Silva EJ, Moreira EJ, de Almeida Neves A, Belladonna FG, Tameirão M. Assessment of apically extruded debris produced by the self-adjusting file system. J Endod 2014; 40: 526-529.

23. Pérez-Higueras JJ, Arias $A$, de la Macorra JC, Peters

$O A$. Differences in cyclic fatigue resistance between Pro-
Taper Next and ProTaper Universal instruments at different levels. J Endod 2014; 40: 1477-1481.

24. Hieawy A, Haapasalo M, Zhou H, Wang ZJ, Shen Y. Phase transformation behavior and resistance to bending and cyclic fatigue of ProTaper gold and ProTaper universal instruments. J Endod 2015; 41: 1134-1138.

25. Pongione G, Pompa G, Milana V, Di Carlo S, Giansiracusa A, Nicolini E, De Angelis F. Flexibility and resistance to cyclic fatigue of endodontic instruments made with different nickel-titanium alloys: a comparative test. Ann Stomatol (Roma) 2012; 3: 119-122.

26. Hülsmann $M$, Peters $O A$, Dummer $P$. Mechanical preparation of root canals: shaping goals, techniques and means. Endod Topics 2005; 10: 30-76.

27. Gagliardi J, Versiani MA, de Sousa-Neto MD, Plazas-Garzon A, Basrani B. Evaluation of the Shaping Characteristics of ProTaper Gold, ProTaper Next, and ProTaper Universal in Curved Canals. J Endod 2015; 41: 1718-1724. 
